\title{
Increase in Pressure
}

National Cancer Institute

\section{Source}

National Cancer Institute. Increase in Pressure. NCI Thesaurus. Code C63080.

Unintended increase in pressure, compromising the device's intended function. 